\title{
A Study of Psychoactive Medicines and Risk of Falls Among Indonesian Elderly Patients
}

\author{
Fita Rahmawati*, Nasikhatul Mustafidah'1,2, I Dewa Putu Pramantara ${ }^{3}$ and Izyan Abdul Wahab ${ }^{4}$
}

1. Department of Pharmacology and Clinical Pharmacy, Faculty of Pharmacy, Universitas Gadjah Mada, Sekip Utara, Yogyakarta, Indonesia 55281

2. Department of Pharmacy, RSUD. Dr Soedono Madiun, Madiun, Jl. Dr. Sutomo No.59, Kartoharjo, Madiun, Jawa Timur 63117 Indonesia

3. Department of Geriatric, RSUP Dr. Sardjito Hospital, Yogyakarta, Indonesia 55281

4. Faculty of Pharmacy, Cyberjaya University College of Medical Sciences, Persiaran Bestari, Cyber 11, 63000 Cyberjaya, Selangor, Malaysia

Info Article
Submitted: $14-01-2019$
Revised: $10-06-2019$
Accepted: $18-06-2019$
*Corresponding author
Fita Rahmawati
Email:
malihahanun@yahoo.com

\section{ABSTRACT}

One of the causes of injury to the elderly is due to falls. Falling can be prevented by identifying and controlling risk factors. One risk factor that can be controlled is the use of fall risk medicines including psychoactive. This study aims to identify the association between the use of psychoactive medicine and its characteristic with the risk of falls among the elderly in Indonesia. The study utilized a case-control study design for a total number of 414 elderly patients, during October until December 2018. Cases were elderly aged 60 years or above with a high risk of falling assessed using the Morse Fall Scale (MFS $\geq 45$ ). Each case was matched with up to two randomly selected controls of the same age who are classified as low to moderate risk of falling (MFS<45). The use of psychoactive medicines was screened from a history of drug use for the past six months. Psychoactive medicine-fall risk associations were estimated via logistic regression. There were 138 cases and 276 controls. The median age of subjects was 66 years old and $54.83 \%$ was a woman. Elderly with a high risk of falling had higher psychoactive medicines use when compare with controls (31.16\% vs $21.38 \%, \mathrm{p}<0.05)$. After adjusting for potential confounders, the use of psychoactive medicines was significantly associated with higher fall risk in elderly patients (OR 1.79 95\% CI 1.10-2.90). Only the duration of psychoactive medication use over 90 days was significantly associated with a high risk of falling (AOR $3.6595 \%$ CI 1.469.14). In elderly patients, the continued use of psychoactive medicines increased the risk of fall. Prescribers need to weigh risk and benefit from the use of psychoactive medicines in the elderly to prevent future fall.

Keywords: Psychoactive medicine, fall risk, elderly, patients.

\section{INTRODUCTION}

The Indonesian elderly population rate is increasing every year. The proportion of the elderly population was $9.77 \%$ in 2010 and predicted to increase to $11.34 \%$ to $21.4 \%$ within 2020 and 2050 (Ministry of Health Republic of Indonesia, 2014). The steep increase in the elderly population is a general health concern because this is a population where multiple chronic diseases and problems are commonly found and usage of medicines is at the highest rate. One of the important health problems commonly found in an older person is fall. The incidence of falls per year in elderly $\geq 64$ years is
$28-35 \%$, whereas elderly $\geq 70$ years is $32-42 \%$. Fall caused serious injury that occurred in 47.7 per 1000 populations (Yoshida, 2007). Fall in the elderly is considered as a major health problem because it can lead to morbidity and mortality (Grundstrom et al., 2013). Fall can be prevented by identifying and controlling fall risk factors. There are multiple risk factors such as intrinsic and extrinsic factors which can contribute to the increment of falls rates. Medication use is categorized as an extrinsic factor for fall in older people (CDC, 2017; WHO, 2007). One of the fall risk medicines is psychoactive medicines. Psychoactive 
medicines are substances that can alter mood, thought processes, or behavior by causing sedation, hypnosis and muscle relaxation (Lindsey, 2009). Studies have shown that psychoactive medicines with sedative property can cause an adverse effect such as fall (Woolcott et al., 2009) by acting on the central nervous system. In addition, the elderly patient had increased blood-brain barrier permeability and receptor sensitivity to psychoactive medicines (Lee et al., 2016). The previous study in Germany revealed that psychoactive drug use was associated with falls in the elderly with OR 1.64 (95\% CI 1.14-2.37) (Du et $a l$, 2017). Another study updated meta-analysis study of psychoactive drugs use and falls in the elderly with OR 1.78 (95\% CI 1.57-2.01) (Bloch et al., 2011). However, the study of psychoactive medication use related to fall risk is limited among Indonesian elderly. Therefore, this study was aimed to identify the association between the use of psychoactive medicine and its characteristic with the risk of falls among the elderly in Indonesia.

\section{MATERIAL AND METHODS}

Study design and subjects

This study was a retrospective case-control study that involved elderly outpatient attending internal medicine and neurology outpatient clinics at two regional general hospitals (RSUD dr. Soedono Madiun and RSUD Kota Madiun) in Madiun city, Indonesia, during October until December 2018. A number of 414 elderly patients were involved in this study with the consent given. Cases were elderly aged 60 years or above with a high risk of falling assessed with the Morse Fall Scale (MFS $\geq 45$ ), while controls were elderly with low to moderate fall risk (MFS $<45)$. The Morse fall Scale is a tool to measure fall risk by means interviews and observations. The MFS was widely used to asses fall risk in patients (Blalock, 2016). In Indonesia, MFS also widely used in practice and in research (Anto, 2015; Lestari, 2015). It is more sensitive than another instrument (Dessy et al., 2013). It consists of six item questions with scoring between 0 and 125 points. The scoring is divided into three, categorized as follows: scoring between 0 and 24 points are at low risk of falls, scoring between 25 and 44 points are at moderate risk of falls and, scoring with 45 points or more are at high risk of falls. Patients classified as high risk were considered exposed to falls (MFS score of 45 or higher), while low and moderate risk patients (MFS between 0-44) were considered not exposed to the event (Costa-Dias et al., 2014; Pasa et al., 2017).

The fall risk assessed when they revisit to hospitals on October-Decembers 2018. The control patients were randomly matched according to age with cases for up to two controls. The history of drugs used and comorbidity were examined and extracted from the medical record. While the use of psychoactive medicines was screened from a history of drug use for the past six months. The inclusion criteria in this study were age $\geq 60$ years, neurology clinic patients who made return visits, patients without physical disabilities, able to communicate, willing to be participants, complete medical records. Elderly patients were excluded if they underwent orthopedic surgery, patients with neurocognitive disorders, and they did not have medical records at pharmacy installations. The Medical and Health Research Ethics Committee (MHREC) of Gadjah Mada University's Faculty of Medicine approved this study (KE/KF/1116/EC/2018).

\section{Characteristics of participant}

The participant was interviewed to fill out the sociodemographic data form. Data on age, gender, height, and weight were collected. The ages were categorized into 3 groups based on BPSStatistics Indonesia categorical, 60-69 years, 70-79 years, and $\geq 80$ years (Badan Pusat Statistik, 2018). Body Mass Index (BMI) is calculated from the ratio of body weight $(\mathrm{kg})$ to the square of the height $(\mathrm{m} 2)$, and categorized into normal $(<25 \mathrm{~kg} / \mathrm{m} 2)$, and abnormal $(\geq 25 \mathrm{~kg} / \mathrm{m} 2)$ (WHO, 2018a). The comorbid were assessed from the medical record. It was scored using the Charlson Comorbidity Index (CCI) (Chan et al., 2014). Otherwise, the use of non-psychoactive medicine related to falls was scored using the Medication Fall Risk Score (MFRS). The non-psychoactive fall risk drugs are Antihypertensive, Cardiac Drugs, Antiarrhythmics, and Diuretics (Ganz et al., 2013).

\section{The characteristics of psychoactive drugs use}

Psychoactive drugs defined based on the classification WHO of Anatomical Therapeutic Chemical (ATC). These drugs involved Opioid Analgetic (N02A), Antimigraine (N02C), Antiepileptic (N03), Antiparkinson (N04), Antipsychotics (N05A), Anxiolytic (N05B), Hypnotic-sedatives (05C), and Antidepressants (N06A) (Pratt and Ramsay, 2014; WHO, 2018b). 
Participants were categorized into using psychoactive medicine if they use the medication with the refill adherence $\geq 100 \%$. The refill adherence defined as the percentage of a number of prescribed treatment days divide number days between fills (Andersson et al., 2005). Anyway, a participant that did not take the medication for 3 days or less also included in this group as they still in the wash-out period (Shuto et al., 2010). The characteristics of psychoactive medicine that evaluate in the study included the duration of drug use, the number of psychoactive drugs, and The Standardized Daily Dose (SDD). The duration of drug use was grouped into 1-30 days, 31-90 days, and $>90$ days. This category based on the insurance policy for the chronic disease patient will receive the medicine periodically every 30 days (Ministry of Health Republic of Indonesia, 2016). The chronic disease usually needs medication over 90 days or longer (National Health Council, 2016). The number of psychoactive drug use are grouped into using 1 psychoactive medicine and $\geq 2$ psychoactive medicines. While the Standardized Daily Dose (SDD) was the ratio of daily dose to DDD (Defined Daily Dose) (Pratt and Ramsay, 2014). The SDD was grouped into 0.1-0.5DDD/day, and >0.5DDD/day. It's based on an earlier study that mostly patient (98\%) were had SDD $<1$ DDD/days.

\section{Statistically analysis}

Statistically, the analysis was performed using the Statistical Package for the Social Sciences (SPSS) software. The categorical data were analyzed using the Chi-square test and the association analysis between independent and dependent variables was derived from logistic regression. $\mathrm{P}$ value was accepted as statistically significant if $\mathrm{p}<0.05$. In this study, the confounding factors were age, gender, BMI, comorbidity (CCI) and the use of nonpsychoactive medicine related to falls (MFRS). The confounding factor controlled by statistical analysis.

\section{RESULT AND DISCUSSION}

There are two fall risk factors, intrinsic factors, and extrinsic factors. Intrinsic factors were demographic factors (race, and socioeconomic status) and biological factors (age, sex, medical conditions/comorbidity, and physical condition's example body mass index). Extrinsic factors were medication intake almost psychoactive drugs, alcohol misuse, and inappropriate shoes (Yoshida,
2007). In this study, the risk factor for falling as an independent variable was psychoactive drug use, while other risk factors were confounding factors. The confounding can be seen as the characteristics of participants (Table I).

\section{Characteristics of participant}

There were 414 elderly patients involved in the study. Where 138 were cases and 276 were controls. The highest percentage $62.56 \%$ (259) of patients was between 60 - 69 years old. In the study entry, the median age of patients was 66 years old with range 60 until 90 years old. This is in line with the results of the census of BPS-Statistics Indonesia in 2017 that Indonesian elderly population was dominated (63\%) by aged 60-69 years (young elderly) (Table I)

On $54.83 \%$ of participants in this study were female and dominated by low comorbidiy (Charlson Comorbidity Index 0-1). This is in line with the result of the census of BPS-Statistic Indonesia that elderly population in 2017 was dominated by female $52,52 \%$. The female elderly patient had longer life expectancy because they had greater awareness of health condition and treatment (Badan Pusat Statistik, 2018). Meanwhile, the body mass index of the participants was dominated $(75.85 \%)$ by normal $(\mathrm{BMI}<25)$ (Table I). Characteristics of participants showing that the case group was similar to the control group in age, gender, BMI and MFRS ( $p>0.05)$, except that the case group was more likely to have higher comorbidity index (Table I).

\section{Description of fall risk}

The study revealed the fall risk in elderly patients in Indonesia had an average of $29.03 \pm 26.67$ (moderate fall risk). This is in line with the results of studies in the Brazilian elderly. They had moderate fall risk with mean MFS of 39.4 \pm 19.4 (Pasa et al., 2017).

The description of fall risk in participants (Table II) shows that female participants and participants with $\mathrm{BMI} \geq 25 \mathrm{~kg} / \mathrm{m}^{2}$ had higher fall risk. The fall risk also increased with age until 80 years old and then began to decrease. It may be due to proportion of elderly patients $\geq 80$ years old was small. The study in line with studies conducted by Alshammari et al. (2018) and Yoshida (2007) revealing that the fall risk was influenced by intrinsic risk factors such as age, sex, physical condition (body mass index) and health conditions. 
Table I. Description of the characteristics of the study participants

\begin{tabular}{|c|c|c|c|c|c|c|c|}
\hline \multirow{2}{*}{ Sociodemography } & & Total $\mathrm{N}=414$ & \multicolumn{2}{|c|}{ Case (MFS $\geq 45) n=138$} & \multicolumn{2}{|c|}{ Control (MFS<45) $n=267$} & \multirow{2}{*}{$\boldsymbol{P}$} \\
\hline & & $\%$ & $\mathbf{n}$ & $\%$ & $\mathbf{n}$ & $\%$ & \\
\hline \multirow{3}{*}{ Age (years) } & $\geq 80$ & $317.49 \%$ & 10 & $7.25 \%$ & 21 & $7.61 \%$ & \\
\hline & $70-79$ & $12429.95 \%$ & 51 & $36.96 \%$ & 73 & $26.45 \%$ & 0.085 \\
\hline & $60-69$ & $25962.56 \%$ & 77 & $55.80 \%$ & 182 & $65.94 \%$ & \\
\hline \multirow{2}{*}{ Gender } & Female & $22754.83 \%$ & 75 & $54.35 \%$ & 152 & $55.07 \%$ & \\
\hline & Male & $18745.17 \%$ & 63 & $45.65 \%$ & 124 & $44.93 \%$ & 0.97 \\
\hline \multirow{2}{*}{ Body Mass Indexs } & $\geq 25$ & $10024.15 \%$ & 41 & $29.71 \%$ & 59 & $21.38 \%$ & ח81 \\
\hline & $<25$ & $31475.85 \%$ & 97 & $70.29 \%$ & 217 & $78.62 \%$ & 81 \\
\hline Charlson & $\geq 2$ & $14835.75 \%$ & 35 & $25.36 \%$ & 113 & $40.94 \%$ & \\
\hline Comorbidity Index & 1 & $21050.72 \%$ & 87 & $63.04 \%$ & 123 & $44.57 \%$ & 0.001 \\
\hline$(\mathrm{CCI})$ & 0 & $5613.53 \%$ & 16 & $11.59 \%$ & 40 & $14.49 \%$ & \\
\hline Non-psychoactive & $\geq 4$ & $9723.43 \%$ & 29 & $21.01 \%$ & 68 & $24.64 \%$ & \\
\hline Fall Risk Drugs in & $1-3$ & $10926.33 \%$ & 43 & $31.16 \%$ & 66 & $23.91 \%$ & 0.274 \\
\hline MFRS & 0 & $20850.24 \%$ & 66 & $47.83 \%$ & 142 & $51.45 \%$ & \\
\hline
\end{tabular}

The analysis using Chi Square test, number in bold are stastistically significant

Tabel II. Description of the risk of falls in the study participants

\begin{tabular}{llc}
\hline Characteristics & & Fall Risk (MFS) (Mean \pm SD) \\
\hline & $\geq 80$ & $29.84 \pm 26.31$ \\
Age (years) & $70-79$ & $32.58 \pm 27.35$ \\
& $60-69$ & $27.24 \pm 26.30$ \\
Gender & Female & $30.00 \pm 27.00$ \\
& Male & $27.86 \pm 26.28$ \\
Body Mass Index (BMI) (Kg/m2) & $\geq 25$ & $33.15 \pm 26.92$ \\
Mean \pm SD & $<25$ & $27.72 \pm 26.49$ \\
\hline
\end{tabular}

SD: Standard Deviation

\section{The characteristics of psychoactive drugs use}

Table III shows the use of psychoactive medicines in elderly patient by 102 (24.64\%.). Such numbers was smaller than in the previous study, or $33.6 \%$ in the Brazilian elderly population (Cabrera et al., 2010). The most psychoactive medicines used by participant were Gabapentin (17.39\%), Diazepam (10.87\%), and Amitriptyline (8.70\%) (Table IV). The use of psychoactive medicines in the case group was statistically and significantly higher than that in the control group $(31.16 \%$ vs $21.38 \%$, $\mathrm{p}<0.05$ ) (Table III). This is consistent with the finding of the previous study in Germany revealing that the elderly with fall had higher psychoactive drugs use (33.1\% vs. 20.7\%) (Du et al., 2017). The characteristics of psychoactive medicines evaluated in the study were duration of drug use, the number of psychoactive drugs, and The Standardized Daily Dose (SDD). (Table III). The Standardized Daily Dose (SDD) $>0.5 \mathrm{DDD} /$ day, the number of psychoactive $\geq 2$ and duration of use $>30$ days in the case group were statistically and significantly higher than that in the control group $(\mathrm{p}<0.05)$. Therefore, they could be candidates to multiple logistic regression analysis $(\mathrm{p}<0.25)$ to derive the influential variables to fall risk.

\section{Association Psychoactive drugs use and fall risk} Overall, this study found that the use of psychoactive medicines was associated with risk of falls (Table V). The use of psychoactive medicines would increase 1.79 times of the risk of falls higher than patients who did not use (95\% CI 1.10-2.90). These results were consistent to previous studies (Bloch et al., 2011; Du et al., 2017; Mustafidah, 2019). A Study conducted in Germany elderly population in 2008-201 revealed that psychoactive drug use was associated with falls in the elderly with OR 1.64 (95\% CI 1.14-2.37) (Du etal., 2017). 
Tabel III. Characteristics of psychoactive drugs use in case group and control group

\begin{tabular}{|c|c|c|c|c|c|c|c|c|}
\hline \multirow{3}{*}{ Characteristic } & \multirow{3}{*}{ Category } & \multicolumn{6}{|c|}{ Group } & \multirow{3}{*}{$p$} \\
\hline & & \multicolumn{2}{|c|}{ Total } & \multicolumn{2}{|c|}{$\begin{array}{c}\text { Case (MFS } \geq 45) \\
n=138\end{array}$} & \multicolumn{2}{|c|}{$\begin{array}{c}\text { Control (MFS<45) } \\
n=276\end{array}$} & \\
\hline & & $\mathbf{n}$ & $\%$ & $\mathbf{n}$ & $\%$ & $\mathbf{n}$ & $\%$ & \\
\hline Psychoactive & Use & 102 & $24.64 \%$ & 43 & $31.16 \%$ & 59 & $21.38 \%$ & \multirow{2}{*}{0.040} \\
\hline Drugs use & No Use & 312 & $75.36 \%$ & 95 & $68.84 \%$ & 217 & $78.62 \%$ & \\
\hline \multirow{2}{*}{ Doses } & $>0.5 \mathrm{DDD} /$ day & 16 & $3.86 \%$ & 10 & $7.25 \%$ & 6 & $2.17 \%$ & \multirow{2}{*}{0.016} \\
\hline & 0.1-0.5 DDD/day & 86 & $20.77 \%$ & 33 & $23.91 \%$ & 53 & $19.20 \%$ & \\
\hline \multirow{3}{*}{ Duration } & >90 days & 31 & $7.49 \%$ & 21 & $15.22 \%$ & 10 & $3.62 \%$ & \multirow{3}{*}{0.000} \\
\hline & 31-90 days & 17 & $4.11 \%$ & 9 & $6.52 \%$ & 8 & $2.90 \%$ & \\
\hline & $1-30$ days & 54 & $13.04 \%$ & 13 & $9.42 \%$ & 41 & $14.86 \%$ & \\
\hline \multirow{2}{*}{ Number } & $>=2$ drugs & 49 & $11.84 \%$ & 30 & $21.74 \%$ & 19 & $6.88 \%$ & \multirow{2}{*}{0.000} \\
\hline & 1 drug & 53 & $12.80 \%$ & 13 & $9.42 \%$ & 40 & $14.49 \%$ & \\
\hline
\end{tabular}

The analysis using Chi Square test, Number in Bold is stastistically significant.

Tabel IV. Description of psychoactive drugs use by study participants

\begin{tabular}{cccc}
\hline No & ATC & Name of Drugs & n (\%) \\
\hline 1 & N03AX12 & GABAPENTIN & $72(17.39 \%)$ \\
2 & N05BA01 & DIAZEPAM & $45(10.87 \%)$ \\
3 & N06AA09 & AMITRIPTYLINE & $36(8.70 \%)$ \\
4 & N04AA01 & TRIHEXYPENIDIL & $9(2.17 \%)$ \\
5 & N04BA02 & LEVODOPA + BENZERAZIDE & $9(2.17 \%)$ \\
6 & N02AX02 & TRAMADOL & $5(1.21 \%)$ \\
7 & N03AB02 & PHENYTOIN & $3(0.72 \%)$ \\
8 & N05AD01 & HALOPERIDOL & $3(0.72 \%)$ \\
9 & N05BA12 & ALPRAZOLAM & $2(0.48 \%)$ \\
10 & N03AA02 & PHENOBARBITAL & $2(0.48 \%)$ \\
\hline
\end{tabular}

Tabel V. Association of psychoactive drugs use and their characteristics with risk of falls

\begin{tabular}{llcccccc}
\hline \multirow{2}{*}{ Psychoactive } & \multicolumn{3}{c}{ Unadjusted } & \multicolumn{3}{c}{ Adjusted } \\
\cline { 3 - 7 } & & OR & Lower & Upper & OR & Lower & Upper \\
\hline Psychoactive drugs use & Use & $\mathbf{1 . 6 6}$ & $\mathbf{1 . 0 5}$ & $\mathbf{2 . 6 4}$ & $\mathbf{1 . 7 9}$ & $\mathbf{1 . 1 0}$ & $\mathbf{2 . 9 0}$ \\
Doses & $>0,5$ DDD/day & 3.81 & $\mathbf{1 . 3 5}$ & $\mathbf{1 0 . 7 8}$ & & NS & \\
Duration & $>90$ days & $\mathbf{4 . 8 0}$ & $\mathbf{2 . 1 8}$ & $\mathbf{1 0 . 5 8}$ & $\mathbf{3 . 6 5}$ & $\mathbf{1 . 4 6}$ & $\mathbf{9 . 1 4}$ \\
Number & $>=2$ drugs & $\mathbf{3 . 6 1}$ & $\mathbf{1 . 9 3}$ & $\mathbf{6 . 7 3}$ & & NS & \\
\hline
\end{tabular}

The analysis using Binary Logistic Regression Test with Backward LR Method, Number in bold are stastistically significant, NS: Non-Statistically Significant. Adjusted: to age, body mass index, and Charlson Comorbidity Index

Another study updated meta-analysis study of psychoactive drugs use and falls in the elderly with OR 1.78 (95\% CI 1.57- 2.01) (Bloch et al., 2011). The only characteristic of psychoactive drug use associated with fall risk was duration of drug use over 90 days, with an Adjusted Odd Ratio of 2.76 (95\% CI 1.15-6.64) (Table V). Compared to other studies, this study investigated the duration of drug use for six month only, while the study conducted by Hanlon et al (2009) assessed the psychoactive drug use for longer duration (5 years). This study stated that psychoactive drug use in short term <2 years had 1.49 times fall risk higher than those who did not use (adjusted OR 1.49 95\% CI 1.11-2.01). The number and dosage of psychoactive medicines (SDD) did not have association with risk of fall, so that it was not consistent with the previous study. Pratt and Ramsay's study in 2014 showed a significantly increased risk of falls when using one or more psychoactive medicines in 
0.1-0.9DDD/day or more. This phenomenon was due to changes of pharmacokinetics and pharmacodynamics of the drugs in elderly patients. The pharmacokinetics changes include increasing of volume distribution of lipid soluble drugs like psychoactive, reduction in hepatic clearance, and also renal clearance, so that it prolongation elimination half-life. Meanwhile pharmacodynamic changes increase sensitivity of the central nervous system as the effects of psychoactive medicines (Lee et al., 2016). These explained that the use of psychoactive medicine in Indonesian elderly was one or more ,but the Standardized Daily Doses (SDD) was low (0.1-0.5DDD/day). However, the potential risk of falls would increase if they used drugs in long term. In this case, the psychoactive medicine will have accumulate, stay longer in the body, and make undesirable effects to the central nervous system in elderly patients (Mangoni and Jackson, 2003).

The results of this study indicated that the use of psychoactive medicine in the elderly needs more attention. To prevent the occurrence of falls in elderly patients, patients and families must be educated about the risk of falling and health professional must collaborate to minimize the use of these drugs by taking their risks and benefits into consideration (Ganz et al., 2013; WHO, 2007). The confounding factors in this study that needs to be controlled were age, body mass index, and comorbidity $(p<0.25)$ (Table I). The result of multivariate analysis using binary logistic regression revealed that the confounding factors significantly influenced to fall risk was age 70-79 years old with OR 1.83 (95\%CI 1.13-2.94). This result was in line with previous studies that age 7079 years old had an odd ratio (OR) 1.36 (95\% CI 1.08-1.72) (Gale et al., 2016). In this study, the age of $\geq 80$ years old was not statistically significantly influence to fall risk. It may be due to the proportion of elderly patients $\geq 80$ years old was small. There was a number of strengths of this study such as an adequate sample of elderly patients in two secondary hospitals involved in this study. We also adjusted to potential confounding factors for falls including age, gender, BMI, comorbidity, and use of non-psychoactive medicine (MFRS). However, this study have limitations, we did not adjust to other potential risk factors for falls such as visual impairments, habit of using footwear, and influence of using non-psychoactive drugs such as nonsteroidal anti-inflammatory drugs (NSAIDS), Antihistamine, and Hypoglycemic agents that were not in the list of Medication Fall Risk Score (MFRS) (Berlie \& Garwood, 2010; WHO, 2007). Therefore, it is expected that they could be analyzed in the future studies.

\section{CONCLUSION}

In elderly patients, the use of psychoactive medicines and continued use of its increased the risk of fall. Therefore, prescribers need to weigh risk and benefit from the use of these medicines in the elderly to prevent future fall.

\section{ACKNOWLEDGMENT}

Authors would like to express their sincere gratitude to the Faculty of Pharmacy UGM for research financial support

\section{REFERENCES}

Alshammari SA., Alhassan AM., Aldawsari MA., Bazuhair FO. and Alotaibi FK. 2018. Falls among elderly and its relation with their health problems and surrounding environmental factors in Riyadh. Journal of Family \& Community Medicine, 25(1), 29-34. https://doi.org/10.4103/jfcm.JFCM

Andersson K., Melander A., Svensson C., Lind O. and Nilsson JLG. 2005. Repeat prescriptions: refill adherence in relation to patient and prescriber characteristics, reimbursement level and type of medication. European Journal of Public Health, 15(6), 621-626. https://doi.org/10.1093/eurpub/cki053

Anto WS. 2015. Pengaruh Penambahan Latihan Keseimbangan Pada Latihan Core Stability Lebih Baik Terhadap Resiko Jatuh Pada Lansia. STIKES Aisyiyah Yogyakarta. Retrieved from http://digilib.unisayogya.ac.id/1921/1/NA SKAH PULIKASI SKRIPSI WIBOWO.pdf

Badan Pusat Statistik (BPS). 2018. Statistik Penduduk Lanjut Usia 2017. Jakarta: Badan Pusat Statistik.

Berlie HD. and Garwood CL. 2010. Diabetes Medications Related to an Increased Risk of Falls and Fall-Related Morbidity in the Elderly, 44, 712-717. https://doi.org/10.1345/aph.1M551

Blalock D. 2016. An Evidenced-Based Approach to Fall Risk Assessment and Management in an Outpatient Imaging Center: Morse Fall Scale. In 43rd Biennial Convention 2015 Theme: Serve Locally, Transform Regionally, Lead Globally. `. Las Vegas, Nevada, USA. 
Bloch F., Thibaud M., Dugué B., Brèque C. and Kemoun G. 2011. Psychotropic Drugs and Falls in the Elderly People: Updated Literature Review and Meta-Analysis. Journal of Aging and Health, 23(2), 329-346. https://doi.org/10.1177/08982643103812 77

Cabrera MAS., Dellaroza MSG., Trelha CS., Paccola L. BB., Perdiga o S da CD. et al., 2010. Psychoactive Drugs as Risk Factors for Functional Decline Among Noninstitutionalized Dependent Elderly People. American Medical Directors Association, 11, 519-522. https://doi.org/ 10.1016/i.jamda.2009.12.001

CDC. 2017. Risk Factors for Falls.

Chan T-C., Luk JK-H., Chu L-W. and Chan F. 2014. Validation study of Charlson Comorbidity Index. Geriatrics \& Gerontology International, 14(2), 452-457. https://doi.org/10.1111_ggi.12129

Costa-Dias MJM. da, Martins T. and Araújo, F. 2014. Study of the cut-off point of the Morse Fall Scale (MFS). Revista de Enfermagem Refer $\tilde{a}^{a}$ cia, $\quad 4(1), \quad 63-72$. https://doi.org/10.12707/RIII13101

Dessy VA., Harmayetty, Widyawati IY. 2013. Penilaian Risiko Jatuh Lanjut Usia (Lansia) Menggunakan Pendekatan Hendrich Falls Scale And Morse Falls Scale. Jurnal Ners, 8(1), 107-117.

Du Y., Wolf IK. and Knopf H. 2017. Association of psychotropic drug use with falls among older adults in Germany. Results of the German Health Interview and Examination Survey for Adults 2008-2011 (DEGS1). PLoS ONE, 12(8), 1-15. https://doi.org/10.1371/ journal.pone.0182432

Gale CR., Cooper C. and Sayer AA. 2016. Prevalence and risk factors for falls in older men and women: The English Longitudinal Study of Ageing. Age and Ageing, 45, 789-794. https://doi.org/10.1093/ageing/afw129

Ganz DA., Huang C., Saliba D., Berlowitz D. and Lukas CV. 2013. Preventing Falls in Hospitals A Toolkit for Improving Quality of Care. Agency for Healthcare Research and Quality, 13-0015-EF.

Grundstrom AC., Guse CE. and Layde PM. 2013. Risk Factors for Falls and Fall-Related Injuries in Adults 85 Years of Age and Older. Arch Gerontol Geriatr, 54(3), 421-428. https://doi.org/10.1016/j.archger.2011.06. 008.Risk
Hanlon JT., Boudreau RM., Roumani YF., Newman A. B., Ruby CM., et al., 2009. Number and dosage of central nervous system medications on recurrent falls in community elders: The health, aging and body composition study. Journals of Gerontology Series A Biological Sciences and Medical Sciences, 64(4), 492-498. https://doi.org/10.1093/gerona/gln043

Lee JK., Mendoza DM., Mohler MJ. and Lee EM. 2016. Geriatrics. In MA. Chisholm-Burns T L. Schwinghammer BG. Wells, P. M. Malone, JM. Kolesar, and JT. DiPiro (Eds.), Pharmacotherapy Principle and Practice (4th ed., pp. 7-18). United State: McGraw-Hill Education.

Lestari LD. 2015. Hubungan Tingkat Kemandirian Dengan Risiko Jatuh Pada Lansia Di Panti Sosial Tresna Werdha Unit Abiyoso Pakem Sleman Yogyakarta. STIKES Jenderal Achmad Yani Yogyakarta. Retrieved from http://repository.unjaya.ac.id/2711/

Lindsey PL. (2009). Psychotropic Medication Use among Older Adults: What All Nurses Need to Know. J Gerontol Nurs. 2009 Sep; 35(9): 28-38.

Mangoni AA., and Jackson SHD. 2003. Age-related changes in pharmacokinetics and pharmacodynamics: basic principles and practical applications: Age-related changes in pharmacokinetics and pharmacodynamics. British Journal of Clinical Pharmacology, 57(1), 6-14. https://doi.org/10.1046/j.13652125.2003.02007.x

Ministry of Health Republic of Indonesia. 2014. Situasi dan Analisa Lanjut Usia. Jakarta.

Ministry of Health Republic of Indonesia. 2016. PMK no 52 Tahun 2016: Standar Tarif Pelayanan Kesehatan Dalam Penyelenggaraan Program Jaminan Kesehatan.

Mustafidah N. (2019). Hubungan Penggunaan Obat Psikoaktif Dengan Risiko Jatuh Pada Pasien Geriatri Rawat Jalan Di Klinik Saraf Rumah Sakit Madiun. Universitas Gadjah Mada.

National Health Council. 2016. About Chronic Conditions.

Pasa TS., Angela M., Baratto M., Morais BX. and Carollo JB. 2017. Risk assessment and incidence of falls in adult hospitalized patients. Rev. Latino-Am. Enfermagem, 25(e2862), 1-8. https://doi.org/ $\underline{10.1590 / 1518-8345.1551 .2862}$ 
Pratt NL. Ramsay EN. 2014. Association Between Use of Multiple Psychoactive Medicines and Hospitalization for Falls: Retrospective Analysis of a Large Healthcare Claim Database. Drug Saf, 37, 529-535. https://doi.org/10.1007/s40264-0140179-2

Shuto H., Imakyure O., Matsumoto J., Egawa T., Jiang, Y., et al., 2010. Medication use as a risk factor for inpatient falls in an acute care hospital: A case-crossover study. British Journal of Clinical Pharmacology, 69(5), 535542. https://doi.org/10.1111/j.13652125.2010.03613.x

WHO. 2007. A Global Report on Falls PreventionEpidemiology of Falls. WHO Report, 1-40. https://doi.org/10.1007/BF02365631
WHO. 2018a. Global Database on Body Mass Index "BMI Classification."

WHO. 2018b. Guideline for ATC classification and DDD assignment 2018. Retrieved from ttps://www.whocc.no/atc_ddd_index/

Woolcott JC, Richardson KJ, Wiens MO, Patel B, Marin J, Khan KM, et al. (2009). Metaanalysis of the impact of 9 medication classes on falls in elderly persons. Arch Intern Med. 2009;169(21):1952-1960. doi: 10.1001/archinternmed.2009.357

Yoshida, S. (2007). A Global Report on Falls Prevention- Epidemiology of Falls. Ageing and Life Course, Family and Community Health, WHO, 1-40. https://doi.org/10.1007/BF02365631 